\title{
Samghabhadra on karma and Momentariness: $b \ddot{j} j a$-theory and Three Other Metaphors
}

\author{
Matsushima Hisakami
}

\section{Introduction}

Interpretations on the notion of avijnapti include whether it is the factor that links karma and its effect. This interpretation might have been proposed on the ground that Vasubandhu introduced the theory of 'seeds (bija)' in his masterpiece the Abhidharmakośa (henceforth $A K B h$ ), in order to nullify and replace Sarvātivāda dharma, i.e., avijñapti, with it. Vasubandhu denies the reality of avijñapti and states that the substance of karma is voli$\operatorname{tion}(\operatorname{cetan} \bar{a})$ and that the connection between karma and its effect should be explained by the bija-theory, or by samtatiparināmaviśeșa-theory. As $A K B h$ has long been considered to be the most important work in Abhidharma literature, it was natural for modern scholars to follow Vasubandhu's position, without examining other Sarvātivāda texts carefully.

To be sure, some scholars have already pointed out that the connecting function doesn't belong to avijñapti, since by definition avijñapti is terminating when a person passes away. Still some scholars insist that avijñapti should be regarded as a sort of karma, as translated 'avijñapti-karma' in Chinese.

Here, the proof of momentariness shed light on this matter. It is well-known that Vasubandhu introduced the proof of momentariness in $A K B h$, which was well-argued and became a model for its later development. Samghabhadra adopted its style with a little modification. So, the momentariness of all conditioned dharmas was their common understanding.

That accepted, it naturally poses a question. How can a momentary karma pruduce its effect, for it doesn't exist when the effect is produced? The answer is found in the Nyāyanusära (henceforth $N A$ ). I would like to give an answer to the long-disputed question based on the relevant portion in $N A$ (T. 29pp. 534c27-535c8). 


\section{Momentary karma can not produce its effect.}

Nyāya-Vaiśesika pointed out as follows:

If all conditioned dharmas are momentary, then karma can't bring about its effect, for karma is also momentary. They give an example of seeds, and claim that seeds produce their sprouts at the very moment when they perish, which means that, having perished, they cannot produce them at a later time. Karmas are also conditioned, and hence, they are momentary. Since they perish without producing their effects, they can never produce their effects, as is the case of seed perishing without producing its sprout. Moreover, once karmas are perished, they cannot be causes, for nonexistents cannot be causes.

\section{1-a. The seed theory of Dārșțāntika}

Probably Dārștāntikas pointed out that karmas cannot produce their fruits if they are momentary. Samghabadra reports that they insisted, in the possibly lost works, as follows:

Seeds produce their fruits not directly, but after producing intermediate sprouts and branches. Thus seeds are not the direct causes which exist just before the fruits, still we can call them "indirect causes", for the continuum beginning with a seed succeeds up to its fruit. The same is true of karmas. The substance of karma, i.e. mind, doesn't cause its effect directly, but the continuum of the mind continues until it produces its effect. Therefore the mind can be called both direct and indirect cause.

In this way, Dārștāntikas distinguish "direct cause" from "indirect cause", and understand that seeds and karmas fall into the latter category. Their metaphor, i. e., the botanical explanation of karma and its effect is well-known, and this "seed theory" is adopted by Kośakāra Vasbandhu. It should be noted that the prototype of his samtatiparināmaviśeșa theory is found here.

\section{1-b. Criticism on Dārștāntika}

Samghabhadra criticizes the Dārștāntika theory of a karmic continuum on two grounds. First, this theory is argued on the ground that only present dharmas exist. Sarvāstivāda standpoint is "the existence of dharmas in the three time periods", and thereby the Dārstāntika theory cannot be accepted. In the first chapter of NA, Samghabhadra criticizes that the Dārștāntika notion of karmic series is not logically acceptable in the case of the definition of avijñapti. That is, he observes that since a continuum consists of more than one parts, it cannot be real. Second, even though the continuum is accepted, the continuum of mind is 
different from that of seed, because the mind loses its function in the state of mindlessness. If karma is, as Dārștāntika insists, the mind in reality there should be a break in the stream of the mind, and a non-Buddhist school's criticism of the Dārșțāntika position would be justifiable.

Sarvāstivāda explains karma as vipāka-hetu. Karma and its effect is also explained with karmic cause (vipāka-hetu) and karmic effect (vipāka-phala). As this karmic cause remains even when the continuum of mind is broken off, namely in the state of mindlessness etc., so does prāpti. From the standpoint of the existence of dharmas in the three time periods, past dharmas have lost their function, but not their capacity (功能* sāmarthya), and thereby it is still possible to produce their effects later. Samghabhadra distinguishes capacity from function, and says that the capacity of past karma could produce its effect.

\section{On the problem that a performer of a action and a receiver of its effect are different.}

Nyāya-Vaiśesika's counter-argument:

Even though the previous explanation is accepted, since the performer is momentary, the receiver of the effect would be different from the performer.

Samghabhadra points out that this argument occurs because the opponent doesn't understand the meaning of the word "different". According to Samghabhadra, there are two meanings of the word "different". One meaning is continuum A and continuum B at the same moment are different. The other meaning is continuum $\mathrm{A}$ at moment 1 and continuum A at moment 2 are different. From the standpoint of momentariness, "different" is used in the second sense. On that ground, it is reasonable to say that the same continuum receives the effect. To show this, he introduces three metaphors.

\section{Metaphor 1; Rice and barley}

Sometimes cause and effect are connected, and sometimes they aren't. [If it is as you say,] then it is as if expecting the sprouts of rice and barley from the seeds of rice.

[Opponent] How is it so?

[Samghabhadra] These two seeds are the same in the sence that they are both different from the sprouts. That is, when you expect the sprouts of rice and barley will be produced from the seed of rice, the same [kind, i.e. the sprout of rice] is connected, but [the sprout of barley is] not connected. If you expect the sprouts of rice and barley will be produced from the seed of rice, these sprouts 
are the same in the sence that both are entities different from the seed of rice. Still if you expect the sprout of rice [from the seed of rice], cause and effect are connected, but if you expect the sprout of barley [from the seed of rice], they are not connnected.

By this metaphor, he shows that continuum $\mathrm{A}$ at the moment 1 and at the moment 2 are connected, but this is not the case for continuum $\mathrm{A}$ and $\mathrm{B}$.

Next, as an example of one and the same continuum(person), Samghabhadra speaks of a fire.

\section{Metaphor 2; The fire burning down a village}

It is like continuity of fire burning a village. A man attempted to burn another village. He ignited a part of a barn, then the fire went on burning until the whole village was burnt down to be ashes. A villager arrested the man, whipped him and forced him to compensate. The man made an excuse and said, "I burned just a building with a small fire. [Since fire is momentary] my fire has gone out. So, I have only to compensate just a handful of grass." He atoned like this. How could he be innocent? Wisemen would understand that the fire which burnt the whole village was produced continuously from the fire the man ignited. Therefore, the man is guilty of burning the whole village.

The point is clear from the metaphor. The direct action of the performer is only ignition, but the result, burning down of the entire village is also caused by the fire. So the man is responsible for everything the fire burnt down, even though the fire is momentary, too. As for skandhas which produce effect after the first and direct skandhas vanished, we should understand that they are the same as the case of the perished seed or fire.

\section{Metaphor 3; The taste of a ripening fruit}

Moreover, it is well-known that the taste of citric acid is produced when the fruit ripens after a series of changing, even then there is no cause of acid.

At the end of the controversy, Samghabhadra gives an example of a fruit endowed with citric acid. Even though it doesn't have the taste before ripening, the ripened fruit owns a sour taste. In the same way, an effect doesn't have a visible cause, but the karma still exists in the past time period, and can produce the fruit. There is no difficulty of explaining the connection between karma and its effect, though we accept momentariness. 


\section{Conclusion}

If we accept that all conditioned dharmas are momentary, then it is natural to raise a question, "how can a karma produce its fruits, for karma vanishes immediately?" To this question, Därștāntikas answered with the metaphor of seed and fruit or the theory of stream of the mind-continuum which was inherited by Vasubandhu. Samghabhadra criticized their theory, and his main point was that mental activities cease when one is in the mindless meditation. He also adopted the metaphor of seed and fruit, but its basis was Sarvāstivāda's theoretical pivot point, the existence of dharmas in the three time periods. According to their thought, even a past karma really exists: it loses its function but still possesses capacity to produce its fruit.

As for the problem that a performer and a receiver would be different if all conditioned dharmas are momentary, Samghabhadra explains that there are two meanings of difference. A person can be said to be different at two different moments, but we don't think there are two different persons. So it is reasonable that the performer of a karma receive the effect at a different moment. As for the cases in which we do not see direct and visible causes, he gives an example of fire or of citric acid, and explains that there are indirect causes even they are invisible. Here, Samghabadra gives three "correct" drșțāntas to criticize Dārṣṭāntikas.

Speaking of avijäpti, its function is not stated here. He explains its function by means of prāpti or the capacity of past dharmas. That means, we'd better not attribute the function of connecting karma and its effect to avijñapti.

\footnotetext{
* References and notes are omitted

〈Key words〉 Samghabhadra, Vasubandhu, kșanika, avijñapti
}

(Graduate Student, Ryukoku University) 